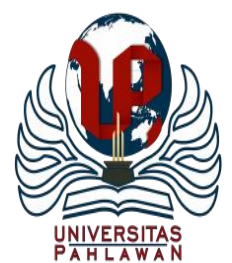

Edukatif : Jurnal Ilmu Pendidikan Volume 3 Nomor 4 Tahun 2021 Halm 1985 - 1996 EDUKATIF: JURNAL ILMU PENDIDIKAN

Research \& Learning in Education

https://edukatif.org/index.php/edukatif/index

\title{
Pengaruh Manajemen Kepala Sekolah dan Kinerja Guru terhadap Minat Belajar Siswa di Sekolah Dasar
}

\author{
Anita Turisia $^{1 凶}$, Suhartono $^{2}$, Rais Hidayat ${ }^{3}$ \\ Universitas Terbuka, Indonesia ${ }^{1}$ \\ Universitas Sebelas Maret, Indonesia ${ }^{2}$ \\ Universitas Pakuan, Indonesia ${ }^{3}$ \\ E-mail : turisiaanita@gmail.com ${ }^{1}, \underline{\text { suhartono@ fkip.uns.ac.id }}^{2}, \underline{\text { rais72rais@gmail.com }}^{3}$
}

\begin{abstract}
Abstrak
Penelitian ini bertujuan untuk: (1) Mendapatkan gambaran tentang pengaruh manajemen kepala sekolah terhadap minat belajar siswa; (2) Mendapatkan gambaran tentang pengaruh kinerja guru terhadap minat belajar siswa; (3) Mendapatkan gambaran tentang pengaruh manajemen kepala sekolah dan kinerja guru terhadap minat belajar siswa. Populasi dalam penelitian ini adalah semua siswa kelas VI, Guru kelas VI dan Kepala Sekolah berjumlah 705 dan sampel yang digunakan adalah 255 dengan teknik Proporsional Random Sampling. Pengumpulan data dilakukan dengan metode angket. Uji validitas dengan teknik analisis Product Moment dan uji reliabilitas menggunakan AlphaCronbach. Uji persyaratan analisis data menggunakan uji normalitas,linearitas, dan multikolinieritas. Pengujian hipotesis menggunakan regresi linier sederhana dan regresi linier berganda.Hasil penelitian ini menunjukkan: (1)terdapat pengaruh antara variabel manajemen kepala sekolah terhadap minat belajar dengan menunjukkan besarnya nilai probabilitas atau sig. (2tiled) adalah 0,000 lebih kecil dari 0,05. Dengan demikian Ho ditolak dan Ha diterima; (2) terdapat pengaruh antara variabel kinerja guru terhadap minat belajar dengan menunjukkanbesarnya nilai probabilitas atau sig. (2-tiled) adalah 0,000 lebih kecil dari 0,05. Dengan demikian Ho ditolak dan Ha diterima; (3) terdapat pengaruh antara variabel manajemen kepala sekolah dan kinerja guru terhadap minat belajar dengan menunjukkan signifikansi tabel ANOVA 0,000 lebih kecil dari 0,05. Dengan demikian Ho ditolak dan Ha diterima.
\end{abstract}

Kata Kunci: Manajemen Kepala Sekolah, Kinerja Guru dan Minat Belajar.

\begin{abstract}
This study aims to: (1) Obtain an overview of the influence of principal management on student interest in learning; (2) Obtain an overview of the effect of teacher performance on student interest in learning; (3) Obtain an overview of the effect of principal management and teacher performance on student interest in learning. The population in this study were all grade VI students, grade VI teachers and the principal used was 705 and the sample used was 255 with proportional random sampling technique. Data collection was done by using a questionnaire method. Validity test using Product Moment analysis technique and reliability test using Alpha Cronbach. Test requirements for data analysis using the normality test, linearity, and multicollinearity. Hypothesis testing uses simple linear regression and multiple linear regression. The results of this study indicate: (1) there is an influence between the principal management variables on interest in learning by showing the value of the probability or sig. (2-tiled) is 0.000 less than 0.05. This Ho was rejected and Ha accepted; (2) there is an influence between teacher performance variables on interest in learning by showing the value of the probability or sig. (2-tiled) is 0.000 smaller than 0.05. This Ho was rejected and Ha accepted; (3) there is an influence between the principal management variable and teacher performance on interest in learning by showing the significance of the 0.000 ANOVA table is smaller than 0.05. This Ho was rejected and Ha accepted
\end{abstract}

Keywords: Principal Management, Teacher Performance and Learning Interest

Copyright (c) 2021 Anita Turisi, Suhartono, Rais Hidayat

$\checkmark$ Corresponding author

Email : turisiaanita@gmail.com

DOI : https://doi.org/10.31004/edukatif.v3i4.1044

ISSN 2656-8063 (Media Cetak)

ISSN 2656-8071 (Media Online) 
1986 Pengaruh Manajemen Kepala Sekolah dan Kinerja Guru terhadap Minat Belajar Siswa di Sekolah DasarAnita Turisi, Suhartono, Rais Hidayat

DOI: https://doi.org/10.31004/edukatif.v3i4.1044

\section{PENDAHULUAN}

Pendidikan di Indonesia memerlukan perhatian yang sangat serius, baik dari pemerintah, masyarakat dan seluruh 'stakeholder'. Untuk melaksanakan pendidikan yang bermutu dibutuhkan sebuah usaha yang matang untuk meningkatkan kualitas SDM. Peningkatan kegiatan pendidikan yang berkualitas harus dilaksanakan secara terencana dan terprogram serta berkesinambungan oleh semua lembaga pendidikan (Nugraha, 2014). Proses peningkatan sumber daya manusia yang bermutu sangatlah penting, oleh karena itu pemerintah dan kalangan swasta telah berupaya bersama-sama untuk mewujudkan pendidikan yang bermutu dengan cara kemajuan pendidikan yang benar-benar berkualitas yaitu dengan memanfaatkan globalisasi perkembangan IPTEK atau dengan me review kurikulum, mengevaluasi program pendidikan, memperbaiki sarana dan prasarana pembelajaran, bahan ajar yang dikembangkan, dan peningkatan kopetensi guru melalui workshop maupun pelatihan.

Berdasarkan hasil observasi yang ada di SD di Kecamatan Karangsaumbung ditemukan bahwa minat belajar siswa masih tergolong rendah dikarenakan kurangnya perhatian siswa terhadap materi yang disampaikan, kurangnya antusias siswa dalam mengikuti pelajaran serta seringnya siswa menunda tugas yang diberikan oleh guru, dalam proses pembelajaran siswa tidak mendengarkan penjelasan guru dan tidak mengikuti dengan baik penjelasan guru, tidak adanya ketertarikan siswa untuk mengikuti pembelajaran, kurangnya perhatian mereka dalam belajar, jarang mencatat materi yang disampaikan guru. Dalam kegiatan diskusi siswa tidak aktif baik dalam bertanya maupun dalam menjawab pertanyaan dari guru.

Kondisi tersebut dapat disebabkan karena kurang minatnya siswa dalam belajar yang dapat dilihat dari kehadiran siswa yang malas berangkat ke sekolah, tidak serius dalam mengikuti proses pembelajaran, siswa jarang mengerjakan tugas yang diberikan guru baik di sekolah maupun di rumah, kurang tertariknya siswa menjawab pertanyaan-pertanyaan yang diberikan oleh guru, siswa kurang perhatian terhadap materi yang diberikan oleh guru, serta kurangnya kesiapan siswa dalam mengikuti pembelajaran. Semua dapat disebabkan karena kurangnya profesionalisme guru yang tidak sesuai dengan harapan karena guru yang mutunya kurang dan dalam memberikan materi pelajaran cenderung monoton karena dalam menggunakan metode tidak inovatif, guru memiliki rasa enggan dalam memperbaiki kegiatan belajar mengajar, misalnya guru hanya menggunakan satu sumber sebagai bahan ajar, padahal banyak sekali sumber bekajar yang dapat digunakan dan mudah diakses.

Peningkatan minat belajar siswa harus ditingkatkan, peningkatan minat belajar tidak dapat terlepas dari peran guru dan kepala sekolah. Dimana menurut Susanto (2016) peran kepala sekolah sebagai seorang pimpinan adalah menjadi kunci dari peningkatan atau perkembangan sekolah. Peningkatan kinerja guru dalam pembelajaran dapat tercapai apabila kepala sekolah sebagai pemimpin mampu memacu guru dalam meningkatkan dengan sungguh-sungguh dan penuh dedikasi yang tinggi terhadap tugas yang diembannya. Guru merupakan satu faktor penentu tinggi rendahnya kualitas pendidikan. Keberhasilan penyelenggaraan Pendidikan sangat ditentukan sejauhmana kesiapan guru dalam menyiapkan peserta didiknya melalui kegiatan belajar mengajar.

Kinerja seorang pendidik adalah hasil yang dicapai oleh pendidik dalam melaksanakan kewajiban yang diberikan kepadanya berdasarkan pada kemampuan, pengalaman dan kesungguhan dalam pemanfaatan waktu (Hasibuan, 2007). Kinerja seorang pendidik dapat diterima, jika pendidik telah melakukan hal-hal yang terdiri dari dedikasi dan kewajiban yang tinggi dalam kegiatan mengajar, mengusai materi belajar dan menguasai kelas serta dapat mengembangkan materi pembelajaran, memiliki disiplin dalam mengerjakan kewajiban sehari-hari, memiliki daya imajinasi yang tinggi dalam proses pembelajaran, serta mampu bekerja sama dengan seluruh warga sekolah, memiliki jiwa kepemimpinan yang dapat menjadi panutan peserta didik, memiliki kepribadian yang baik, jujur, dan objektif dalam memberikan bimbingan kepada siswa, serta tanggungjawab terhadap tugas-tugasnya. Hasil belajar siswa dapat ditingkatkan melalui peningkatan minat 
1987 Pengaruh Manajemen Kepala Sekolah dan Kinerja Guru terhadap Minat Belajar Siswa di Sekolah DasarAnita Turisi, Suhartono, Rais Hidayat

DOI: https://doi.org/10.31004/edukatif.v3i4.1044

belajar siswa. Artinya semakin baik minat belajar siswa maka akan berdampak pada hasil belajar siswa yang akan semakin baik pula (Nurhasanah \& Sobandi, 2016).

Keberhasilan kegiatan pembelajaran tidak hanya ditentukan oleh guru, tetapi peran kepala sekolah harus berjalan, dimana kepala harus memberikan perhatian kepada guru dalam kegiatan pembelajaran, misalnya kepala sekolah mampu memberi contoh para guru agar mengajar lebih baik dengan memfasilitasi sarana prasarana yang mendukung untuk pembelajaran, sehingga nantinya pembelajaran yang dilakukan menjadi lebih menarik. Guru-guru diberikan kesempatan untuk mengikuti pelatihan dalam penggunaan media pembalajaran yang interaktif, yang setelah mengikuti pelatihan guru mampu mengaplikasikan dalam proses pembelajaran sehingga pembelajaran menjadi bermakna dan menarik yang dapat menumbahkan minat siswa. Selain dapat meningkatkan minat belajar hal tersebut dapat meningkatkan kinerja guru. Kepala sekolah juga dapat meningkatkan minat belajar siswa dengan fasilitas yang lengkap seperti perpustakaan yang memadai, ruang belajar yang nyaman, sekolah yang asri, serta pendukung lainnya (Raharjo \& Yuliana, 2016).

Menurut Griffin bahwa manajemen adalah suatu rangkaian aktivitas (termasuk perencanaan dan pengambilan keputusan, pengorganisasian, kepemimpinan, dan pengendalian) yang diarahkan pada berbagai sumber daya organisasi (Kurniatun \& Suryana, 2016). Manajemen memuat empat aspek di antaranya perencanaan dan pengambilan keputusan, pengorganisasian, pengendalian, dan kepemimpinan. Manajemen tidak hanya ditemukan di organisasi, atau lembaga tertentu, tetapi di yayasan sekolah karena untuk memutuskan kebijakan yang harus dilaksanakan dalam pembelajaran. Bagian penting dari manajemen yaitu membuat program pengajaran dan pembelajaran dan mengalokasikan kewajiban setiap pendidik, karena pendidik sebagai instruktur, seharusnya kepala sekolah harus memiliki hubungan yang baik untuk membangun korespondensi yang dinamis. Sehingga pendidik dapat melakukan kewajibannya dengan tepat.

Menurut Urwick fungsi manajemen terdiri dari staffing, planning, organizing, controlling, directing, dan coordinating (Herujito, 2004). Berdasarkan fungsi tersebut maka kepala sekolah sebagai seorang manajer harus dapat menjalankan fungsinya terutama dalam controlling yang dapat memberikan penilaian, dan jika kurang pas dapat memberikan koreksi untuk untuk diarahkan ke jalan yang telah digariskan semula. Hubungan antara kepala sekolah dan pendidik harus harmonis, tugas bergantung pada kepercayaan, kesetiaan, ketulusan dan partisipasi. Rendahnya maanajerial kepala sekolah disebabkan oleh beberapa hal, khususnya: 1) pelaksanaan pendaftaran kepala sekolah yang belum berpegang pada prinsip yang sah. 2) ketiadaan informasi tentang manajerial yang berakibat kepala sekolah dalam menyelesaikan kewajibannya hanya menggunakan kebiasaan.

Hasil penelitian menunjukkan (1) tugas kepala sekolah sebagai pimpinan perubahan adalah bertugas sebagai visioner, melatih, memicu, dan rekan kerja, (2) metodologi yang digunakan oleh kepala sekolah adalah untuk meningkatkan manajerial siswa dan manajerial gurudan karyawan, menumbuhkan budaya sekolah, mengatur pembelajaran, dan mengatur hasil dengan maksimal (Zahro et al., 2018). Berdasarkan hasil penelitian tersebut bahwa strategi untuk meningkatkan mutu pendidikan dengan memperbaiki manajemen peserta didik, disini berarti bahwa manajerial kepala sekolah mempengaruhi minat belajar, kerena minat belajar bagian dari manajemen peserta didik.

Teori yang mendukung manajerial kepala sekolah mempengaruhi minat belajar siswa adalah teori James memaparkan bahwa kepala sekolah harus melakukan lima aktivitas utama, antara lain: 1) merumuskan visi untuk kemajuan akademik siswa; 2) menciptakan suasana sekolah yang sangat layak untuk pendidikan dan pembelajaran; 3) menanamkan sikap kepemimpinan terhadap seluruh staf akademik dan non-akademik; 4) meningkatkan pembelajaran, dan 5) mengelola seluruh staf akademik dan non-akademik untuk mengelola proses layanan akademik dan non-akademik dalam rangka mempercepat kemajuan (Fitrah, 2017).

Hasil penelitian yang di terbitkan dalam jurnal Internasional mengenai The influence of principal leadership, teacher learning characteristics, and utilization facilities on student thinking skill. The results showed that a positive relationship existed between the principal leadership variables, characteristics of 
1988 Pengaruh Manajemen Kepala Sekolah dan Kinerja Guru terhadap Minat Belajar Siswa di Sekolah DasarAnita Turisi, Suhartono, Rais Hidayat

DOI: https://doi.org/10.31004/edukatif.v3i4.1044

teacher learning, and utilization of learning facilities in the formation of student thinking abilities. Principal leadership and teacher learning characteristics show indirect effects through the use of learning facilities that are large compared to direct influence. For this reason, it is recommended that: (1) Training be provided to principals to be visionary, achievement oriented, and able to realize the role of facilitator and motivator, and also monitor and supervise the learning and utilization of learning facilities by the teacher;(2) teachers should be trained on utilizing the PBL approach and learning facilities in schools and other sources;(3) regulations should be issued to involve parental participation, especially in supporting the provision of learning facilities (Zakso et al., 2018).

Berdasarkan pemaparan data mengenai kondisi minat belajar siswa di atas dan berbagai sumber literatur dan penelitian terdahulu yang mejadi latar belakang dilakukannya penelitian ini untuk mencari nilai-nilai kebaruan atau novelty. Setelah di telaah dan dianalisis bahwa dalam peneitian-penelitian sebelumnya belum ada yang meneliti manajerial kepala sekolah mempengaruhi minat belajar siswa. Oleh karena itu, peneliti menganggap perlu untuk meneliti tentang "Pengaruh Manajemen Kepala Sekolah Dan Kinerja Guru Terhadap Minat Belajar Siswa Kelas VI SD Se-Kecamatan Karangsambung”.

\section{METODE PENELITIAN}

Penelitian ini menggunakan penelitian kuantitatif, menurut Sugiyono (2017:14) dapat diartikan sebagai metode penelitian yang berlandaskan pada filsafat positivisme, digunakan untuk meneliti pada populasi atau sampel tertentu, Populasi dalam penelitian ini adalah 1) semua siswa kelas VI SD Se-Kecamatan Karangsambung tahun pelajaran 2020/2021. Jumlah sekolah dasar yang ada di Kecamatan Karangsambung adalah 26 Sekolah Dasar Negeri dengan jumlah siswa kelas 6 secara keseluruhan putra berjumlah 332 siswa dan putri 320 siswa jumlah seluruhnya 652 siswa. 2) Guru kelas VI SD sekecamatan Karangsambung yang berjumlah 29 orang. 3) Kepala Sekolah Dasar Negeri di wilayah Kecamatan karangsambung yang berjumlah 24 orang. Sehingga total populasi dalam penelitian ini berjumlah 705 . Berdasarkan jumlah populasi sebanyak 705 diambil 255 sebagai sampelnya dengan taraf kesalahan 5\% dengan teknik penentuan sampel menggunakan rumus Taro Yamane. Banyaknya sampel diambil dengan teknik Proporsional Random Sampling karena pengambilan sampel dari anggota populasi secara acak dan berstrata secara proporsional dengan anggota populasinya heterogen atau tidak sejenis.

Instrumen yang digunakan dalam penelitian ini adalah angket, angket digunakan untuk mendapatkan data mengenai manajemen kepala sekolah, kinerja guru dan minat belajar. Skala yang digunakan adalah skala liekert dengan empat alternatif jawaban yaitu: $\mathrm{SL}=$ Selalu dengan skor 4, SR=Sering dengan skor 3, KD = Kadang-Kadang dengan skor 2, TP = Tidak Pernah. Uji validitas dengan teknik analisis Product Moment dan uji reliabilitas menggunakan Alpha Cronbach. Uji persyaratan analisis data menggunakan uji normalitas, linearitas, dan multikolinearitas. Pengujian hipotesis menggunakan regresi sederhana dan regresi berganda.

\section{HASIL DAN PEMBAHASAN PENELITIAN}

\section{Hasil Analisis Deskriptif Variabel Penelitian}

Data variabel minat belajar didapatkan melalui angket dengan total soal 22 soal. Output statistic deskriptif menunjukkan bahwa total responden sebesar 255 responden total skor yang didaptkan pada data minat belajar sebesar 19663. Berdasarkan output SPSS terlihat nilai terendah adalah 54, nilai tertinggi adalah 88 , mean 77,11, standar deviasi 6,466. Berdasarkan hasil tersebut memperlihatkan bahwa data minat belajar merupakan data yang baik dikarenakan besaran standar deviasi lebih kecil dari mean.

Data manajemen kepala sekolah didapatkan melalui angket dengan total soal 23 soal. Output SPSS statistik deskriptif menunjukkan bhwa melalui 255 responden didapatkan data manajemen kepala sekolah 
1989 Pengaruh Manajemen Kepala Sekolah dan Kinerja Guru terhadap Minat Belajar Siswa di Sekolah DasarAnita Turisi, Suhartono, Rais Hidayat

DOI: https://doi.org/10.31004/edukatif.v3i4.1044

sebesar 19637. Berdasarkan output SPSS terlihat nilai terendah adalah 59, nilai tertinggi adalah 92, mean 77,01, standar deviasi 6,552. Berdasarkan hasil tersebut memperlihatkan bahwa data manajemen kepala sekolah merupakan data yang baik dikarenakan besaran standar deviasi lebih kecil dari mean.

Data kinerja guru didapatkan melalui angket dengan total soal 22 soal. Output SPSS statistik deskriptif menunjukkan bhwa melalui 255 responden didapatkan data kinerja guru sebesar 19395. Berdasarkan output SPSS terlihat nilai terendah adalah 55, nilai tertinggi adalah 88, mean 76,06, standar deviasi 6,226. Berdasarkan hasil tersebut memperlihatkan bahwa data kinerja guru merupakan data yang baik dikarenakan besaran standar deviasi lebih kecil dari mean.

\section{Hasil Analisis Uji Prasyarat}

Uji normalitas bertujuan untuk menguji apakah dalam model regresi, variabel penganggu atau residual berdistribusi normal. Kriteria data yang berdistribusi normal penting untuk dipenuhi dan merupakan syarat yang harus dipenuhi dalam pengujian hipotesis penelitian. Teknik pengujian normalitas yang digunakan dalam penelitian ini adalah uji Kolmogorov Smirnov. Berdasarkan hasil perhitungan normalitas data dengan SPSS 25.0:

Tabel 1. Tabel Uji Normalitas

\section{One-Sample Kolmogorov-Smirnov Test}

\begin{tabular}{llr}
\hline \multicolumn{2}{c}{ One-Sample Kolmogorov-Smirnov Test } \\
N & Unstandardized Residual \\
Normal Parameters ${ }^{\mathrm{a}, \mathrm{b}}$ & Mean & 255 \\
& Std. Deviation & .0000000 \\
Most Extreme & Absolute & 3.07260116 \\
Differences & Positive & .055 \\
& Negative & .054 \\
Test Statistic & & .055 \\
Asymp. Sig. (2-tailed) & .878 \\
a. Test distribution is Normal. & .425 \\
b. Calculated from data. & \\
c. Lilliefors Significance Correction. \\
d. This is a lower bound of the true significance. \\
\hline
\end{tabular}

Output tersebut, diketahui bahwa harga signifikansi Asymp. Sig. (2-tailed) sebesar 0.425 lebih besar dari 0.05. Maka sesuai dengan pengambilan keputusan dalam uji normalitas kolomogrov-smirnov di atas, dapat disimpulkan bahwa data berdistribusi normal. Dengan demikian, asumsi atau persyaratan normalitas dalam model regresi terpenuhi.

Uji linearitas bertujuan untuk mengetahui apakah spesifikasi model yang digunakan berbentuk linear. Data dikatakan linier apabila antara variabel independent dengan variabel dependent tidak ada sebuah penyimpangan. Pengujian linineritas dengan menggunakan bantuan SPSS 25.0. Dari uji linearitas yang dilakukan diperoleh output:

Tabel. 2. Hasl Uji Linieritas Manajemen Kepala Sekolah dengan Minat Belajar

\begin{tabular}{llllllll}
\hline \multicolumn{7}{c}{ ANOVA Table } \\
\hline & $\begin{array}{l}\text { Sum of } \\
\text { Squares }\end{array}$ & df & \multicolumn{1}{c}{$\begin{array}{c}\text { Sean } \\
\text { Square }\end{array}$} & F & Sig. \\
\hline $\begin{array}{l}\text { minat belajar * } \\
\text { manajemen } \\
\text { kepala sekolah }\end{array}$ & Between & Groups & 7321.545 & 30 & 244.052 & 16.569 & .000 \\
\cline { 2 - 8 } & Linearity & 6805.532 & 1 & 6805.532 & 462.038 & .000 \\
\cline { 2 - 8 } & $\begin{array}{l}\text { Deviation from } \\
\text { Linearity }\end{array}$ & 516.014 & 29 & 17.794 & 1.208 & .223 \\
\hline
\end{tabular}


1990 Pengaruh Manajemen Kepala Sekolah dan Kinerja Guru terhadap Minat Belajar Siswa di Sekolah DasarAnita Turisi, Suhartono, Rais Hidayat

DOI: https://doi.org/10.31004/edukatif.v3i4.1044

\begin{tabular}{lrrr} 
Within Groups & 3299.380 & 224 & 14.729 \\
\hline Total & 10620.925 & 254 &
\end{tabular}

Berdasarkan output SPSS 25.0 di atas harga Deviation from Linearity Sig. yaitu 0,223 lebih besar dari 0,05. Hal tersebut berarti terdapat hubungan linier secara signifikan manajemen kepala sekolah dengan variable minat belajar

Tabel. 3. Hasl Uji Linieritas Variabel Kinerja Guru dengan Minat Belajar

\begin{tabular}{|c|c|c|c|c|c|c|c|}
\hline \multicolumn{8}{|c|}{ ANOVA Table } \\
\hline & & & $\begin{array}{l}\text { Sum of } \\
\text { Squares }\end{array}$ & df & $\begin{array}{l}\text { Mean } \\
\text { Square }\end{array}$ & $\mathrm{F}$ & Sig. \\
\hline \multirow{5}{*}{$\begin{array}{l}\text { minat belajar * } \\
\text { kinerja guru }\end{array}$} & \multicolumn{2}{|c|}{ Between (Combined) } & 8525.329 & 30 & 284.178 & 30.376 & .000 \\
\hline & \multirow[t]{2}{*}{ Groups } & Linearity & 8137.900 & 1 & 8137.900 & 869.867 & .000 \\
\hline & & $\begin{array}{l}\text { Deviation from } \\
\text { Linearity }\end{array}$ & 387.429 & 29 & 13.360 & 1.428 & .080 \\
\hline & \multicolumn{2}{|c|}{ Within Groups } & 2095.597 & 224 & 9.355 & & \\
\hline & \multicolumn{2}{|l|}{ Total } & 10620.925 & 254 & & & \\
\hline
\end{tabular}

Berdasarkan output SPSS 25.0 di atas harga Deviation from Linearity Sig. yaitu 0,080 lebih besar dari 0,05 . Hal tersebut berarti ada hubungan linier secara signifikan antara kinerja guru dengan minat belajar (Y).

\section{Uji Multikolinieritas}

Uji multikolinieritas ini bertujuan untuk membuktikan atau menguji ada tidaknya korelasi di antara variable bebas (independent) satu dengan variabel bebas (independent) yang lainnya. Dari hasil SPSS 25.0 uji multikolinieritas diperoleh hasil:

Tabel 4. Hasil Analisis Multikolinieritas

\begin{tabular}{|c|c|c|c|c|c|c|c|c|}
\hline \multicolumn{9}{|c|}{ Coefficients $^{\mathrm{a}}$} \\
\hline & & \multicolumn{2}{|c|}{$\begin{array}{l}\text { Unstandardize } \\
\text { d Coefficients }\end{array}$} & $\begin{array}{l}\text { Standardized } \\
\text { Coefficients } \\
\end{array}$ & \multirow[b]{2}{*}{$\mathrm{T}$} & \multirow[b]{2}{*}{ Sig. } & $\begin{array}{r}\text { Collinea } \\
\text { Statisti }\end{array}$ & $\begin{array}{l}\text { rity } \\
\text { cs }\end{array}$ \\
\hline \multicolumn{2}{|c|}{ Model } & B & $\begin{array}{l}\text { Std. } \\
\text { Error }\end{array}$ & Beta & & & Tolerance & VIF \\
\hline \multirow[t]{3}{*}{1} & (Constant) & 6.512 & 2.422 & & 2.689 & .008 & & \\
\hline & $\begin{array}{l}\text { manajemen kepala } \\
\text { sekolah }\end{array}$ & .175 & .059 & .177 & 2.989 & .003 & .256 & 3.913 \\
\hline & kinerja guru & .751 & .061 & .723 & 12.205 & .000 & .256 & 3.913 \\
\hline
\end{tabular}

a. Dependent Variable: minat belajar

Berdasarkan table output di atas harga Tolerance pada manajemen kepala sekolah serta kinerja guru yaitu 0.256 lebih tinggi dari 0.10 . sedangkan harga VIF manajemen kepala sekolah dan kinerja guru yaitu 3.913 lebih kecil 10.00. hal tersebut berarti tidak terjadi multikolinieritas.

\section{Analisis Regeresi Linier Sederhana Variable Manajemen Kepala Sekolah terhadap Minat Belajar}

Analisi regresi pada penelitian ini menggunakan bantuan SPSS 25.0, adapun hasil analisis regresinya sebagai berikut: 
1991 Pengaruh Manajemen Kepala Sekolah dan Kinerja Guru terhadap Minat Belajar Siswa di Sekolah DasarAnita Turisi, Suhartono, Rais Hidayat

DOI: https://doi.org/10.31004/edukatif.v3i4.1044

Tabel 5. Persentase Pengaruh Variabel Manajemen Kepala Sekolah terhadap Minat Belajar

\begin{tabular}{|c|c|c|c|c|}
\hline \multicolumn{5}{|c|}{ Model Summary $^{\mathbf{b}}$} \\
\hline Model & $\mathrm{R}$ & R Square & Adjusted R Square & $\begin{array}{l}\text { Std. Error of the } \\
\text { Estimate }\end{array}$ \\
\hline 1 & $.800^{\mathrm{a}}$ & .641 & .639 & 3.883 \\
\hline \multicolumn{5}{|c|}{ a. Predictors: (Constant), manajemen kepala sekolah } \\
\hline b. Depe & riable: $n$ & minat belaja & & \\
\hline
\end{tabular}

Berdasarkan output di atas menjelaskan besarnya presentase penngaruh variabel bebas terhadap variabel terikat. Besarnya nilai $\mathrm{R}$ Square yaitu 0.641 , hal tersebut berarti bahwa variabel indpendent yaitu manajemen kepala sekolah terhadap perubahan variabel terikat dependent yaitu minat belajar adalah $64,1 \%$. Sedangkan 35,9\% (100\% - 64,1\%) dipengaruhi oleh variabel lain.

Tabel 6. Hasil Analisis Rergresi Linier Manajemen Kepala Sekolah terhadap Minat Belajar

\begin{tabular}{llrrrrr}
\hline \multicolumn{7}{c}{ ANOVA $^{\mathbf{b}}$} \\
\multirow{2}{*}{ Model } & \multicolumn{1}{c}{$\begin{array}{c}\text { Sum of } \\
\text { Squares }\end{array}$} & \multicolumn{1}{c}{ Df } & Mean Square & \multicolumn{1}{c}{ F } & \multicolumn{1}{c}{ Sig. } \\
\hline \multirow{2}{*}{1} & Regression & 6805.532 & 1 & 6805.532 & 451.277 & $.000^{\mathbf{a}}$ \\
\cline { 2 - 7 } & Residual & 3815.394 & 253 & 15.081 & & \\
\cline { 2 - 7 } & Total & 10620.925 & 254 & & & \\
\hline
\end{tabular}

a. Predictors: (Constant), manajemen kepala sekolah

b. Dependent Variable: minat belajar

Berdasarkan tabel di atas nilai signifikan 0,000. signifikan tabel ANOVA 0,000 kurang dari 0,05.

Hal tersebut berarti Ho di tolak dan Ha diterima. Kesimpulannya terdapat pengaruh antara manajemen kepala sekolah terhadap minat belajar.

Tabel 7. Hasil Perhitungan Nilai B Persamaan Regresi Manajemen Kepala Sekolah terhadap Minat Belajar

Coefficients $^{\mathrm{a}}$

\begin{tabular}{|c|c|c|c|c|c|c|c|c|c|c|}
\hline \multirow{2}{*}{\multicolumn{2}{|c|}{ Model }} & \multicolumn{2}{|c|}{$\begin{array}{l}\text { Unstandardized } \\
\text { Coefficients }\end{array}$} & \multirow{2}{*}{$\begin{array}{c}\text { Standardized } \\
\text { Coefficients } \\
\text { Beta }\end{array}$} & \multirow[b]{2}{*}{$\mathrm{T}$} & \multirow[b]{2}{*}{ Sig. } & \multicolumn{2}{|c|}{$\begin{array}{l}\text { Confidence } \\
\text { Interval for B }\end{array}$} & \multicolumn{2}{|c|}{$\begin{array}{l}\text { Collinearity } \\
\text { Statistics }\end{array}$} \\
\hline & & B & $\begin{array}{l}\text { Std. } \\
\text { Error }\end{array}$ & & & & $\begin{array}{l}\text { Lower } \\
\text { Bound }\end{array}$ & $\begin{array}{l}\text { Upper } \\
\text { Bound }\end{array}$ & \multirow[t]{2}{*}{ Tolerance } & \multirow[t]{2}{*}{ VIF } \\
\hline 1 & (Constant) & 15.991 & 2.887 & & 5.538 & .000 & 10.305 & 21.677 & & \\
\hline & $\begin{array}{l}\text { manajemen } \\
\text { kepala } \\
\text { sekolah }\end{array}$ & .794 & .037 & .800 & 21.243 & .000 & .720 & .867 & 1.000 & 1.000 \\
\hline
\end{tabular}

a. Dependent Variable: minat belajar

Berdasarkan tabel coefficients di atas kolom B pada constant (a) adalah 15,991, sedangkan nilai manajemen kepala sekolah (b) 0,794 . Sehingga persamaan regresinya dapat ditulis sebagai berikut:

$\mathrm{Y}=\mathrm{a}+\mathrm{bX}$

$\mathrm{Y}=15,991+0,794 \mathrm{X}$

Berdasarkan hasil perhitungan diperoleh $b=0,794$ bertanda positif ini berarti setiap kali variabel manajemen kepala sekolah bertambah satu, berarti rata-rata minat belajar bertambah 0,794. Besarnya nilai $t$ dapat menjadi petunjuk dalam mengetahui pengaruh manajemen kepala sekolah terhadap minat belajar. Apabila Ho ditolak (sig. $\leq 0,05$ ) yang maksudnya terdapat pengaruh, dan apabila Ho diterima (sig. > 0,05) yang maksudnya tidak ada pengaruh. Berdasarkan output SPSS 25.0 besarnya sign. 0,000 
1992 Pengaruh Manajemen Kepala Sekolah dan Kinerja Guru terhadap Minat Belajar Siswa di Sekolah DasarAnita Turisi, Suhartono, Rais Hidayat

DOI: https://doi.org/10.31004/edukatif.v3i4.1044

kurang dari 0,05. Hal tersebut menunjukkan bahwa Ho ditolak dan Ha diterima yang bermaksud terdapat pengaruh antara manajemen kepala sekolah terhadap minat belajar.

\section{Analisis Regeresi Linier Sederhana Variable Kinerja Guru (X2) terhadap Minat Belajar (Y)}

Analisi regresi pada penelitian ini menggunakan bantuan SPSS 25.0, adapun hasil analisis regresi sederhana antara kinerja guru dengan minat belajar adalah sebagai berikut:

Tabel. 8. Koefisien Determinasi Pengaruh Variabel Kinerja Guru terhadap Minat Belajar

\section{Model Summary ${ }^{b}$}

\begin{tabular}{|c|c|c|c|c|}
\hline Model & $\mathrm{R}$ & R Square & Adjusted R Square & $\begin{array}{l}\text { Std. Error of the } \\
\text { Estimate }\end{array}$ \\
\hline 1 & $.875^{\mathrm{a}}$ & .766 & .765 & 3.133 \\
\hline \multicolumn{5}{|c|}{ a. Predictors: (Constant), kinerja guru } \\
\hline
\end{tabular}

Berdasarkan output di atas menjelaskan besarnya presentase penngaruh variabel independent terhadap variabel dependent. Nilai R Square yaitu 0,766 yang berarti bahwa indpendent yaitu kinerja guru terhadap perubahan variabel dependent yaitu minat belajar yaitu $76,6 \%$ dan $23,4 \%(100 \%$ $76,6 \%$ ) dipengaruhi oleh variabel lain selain variabel kinerja guru.

Tabel 9. Hasil Analisis Rergresi Linier Kinerja Kerja terhadap Minat Belajar

\begin{tabular}{|c|c|c|c|c|c|c|}
\hline \multicolumn{7}{|c|}{ ANOVA $^{b}$} \\
\hline Model & & $\begin{array}{l}\text { Sum of } \\
\text { Squares }\end{array}$ & Df & $\begin{array}{l}\text { Mean } \\
\text { Square }\end{array}$ & $\mathrm{F}$ & Sig. \\
\hline \multirow[t]{3}{*}{1} & Regression & 8137.900 & 1 & 8137.900 & 829.185 & $.000^{\mathrm{a}}$ \\
\hline & Residual & 2483.026 & 253 & 9.814 & & \\
\hline & Total & 10620.925 & 254 & & & \\
\hline
\end{tabular}

a. Predictors: (Constant), kinerja guru

b. Dependent Variable: minat belajar

Berdasarkan output tersebut nilai signifikan 0,000. Sign. tabel ANOVA 0,000 kurang dari 0,05. Hal tersebut bahwa Ho ditolak dan Ha diterima yang berarti terdapat pengaruh antara kinerja guru terhadap minat belajar.

Tabel 10. Hasil Perhitungan Nilai B Persamaan Regresi Kinerja Guru terhadap Minat Belajar

\begin{tabular}{|c|c|c|c|c|c|c|c|c|}
\hline \multirow[b]{3}{*}{ Model } & \multicolumn{7}{|c|}{ Coefficients $^{\mathrm{a}}$} & \\
\hline & \multicolumn{2}{|c|}{$\begin{array}{l}\text { Unstandardize } \\
\text { d Coefficients }\end{array}$} & \multirow{2}{*}{$\begin{array}{c}\text { Standardized } \\
\text { Coefficients } \\
\text { Beta }\end{array}$} & \multirow[b]{2}{*}{$\mathrm{T}$} & \multirow[b]{2}{*}{ Sig. } & \multicolumn{2}{|c|}{$\begin{array}{l}\text { 95\% Confidence } \\
\text { Interval for B }\end{array}$} & $\begin{array}{l}\text { Collinearity } \\
\text { Statistics }\end{array}$ \\
\hline & B & $\begin{array}{l}\text { Std. } \\
\text { Error }\end{array}$ & & & & $\begin{array}{l}\text { Lower } \\
\text { Bound }\end{array}$ & $\begin{array}{l}\text { Upper } \\
\text { Bound }\end{array}$ & Tolerance VIF \\
\hline 1 (Constant) & 7.963 & 2.409 & & 3.305 & .001 & 3.218 & 12.708 & \\
\hline kinerja guru & .909 & .032 & .875 & 28.796 & .000 & .847 & .971 & 1.0001 .000 \\
\hline
\end{tabular}

a. Dependent Variable: minat belajar

Berdasarkan tabel coefficients di atas kolom B pada constant (a) adalah 7,963, sedangkan nilai kinerja guru (b) 0,909 . Sehingga persamaan regresinya dapat ditulis sebagai berikut:

$\mathrm{Y}=\mathrm{a}+\mathrm{bX}$

$\mathrm{Y}=7,963+0,909 \mathrm{X}$

Berdasarkan output SPSS diperoleh $b=0,909$ bertanda positif ini berarti setiap kali variabel kinerja guru bertambah satu, maka rata-rata minat belajar bertambah 0,909. Besarnya signifikansi 
1993 Pengaruh Manajemen Kepala Sekolah dan Kinerja Guru terhadap Minat Belajar Siswa di Sekolah DasarAnita Turisi, Suhartono, Rais Hidayat

DOI: https://doi.org/10.31004/edukatif.v3i4.1044

dijadikan pedoman dalam mengetahui pengaruh kinerja guru terhadap minat belajar. Apabila Ho ditolak (sig. $\leq 0,05$ ) yang maksudnya terdapat pengaruh, dan apabila Ho diterima (sig. $>0,05$ ) berarti tidak ada pengaruh. Berdasarkan output SPSS 25.0 bahwa besarnya sign. 0,000 kurang dari 0,05. Hal tersebut menunjukkan bahwa Ho ditolak dan Ha diterima yang maksudnya bahwa kinerja guru berpengaruh terhadap minat belajar.

\section{Analisis Regresi Linear Berganda}

Analisi regresi pada penelitian ini menggunakan bantuan SPSS 25.0, adapun hasil analisis regresi berganda antara manajemen kepala sekolah dan kinerja guru dengan minat belajar adalah sebagai berikut; Tabel 11. Koefisien determinasi Manajemen Kepala Sekolah dan Kinerja Guru terhadap Minat Belajar

\begin{tabular}{lccccc}
\hline \multicolumn{5}{c}{ Model Summary $^{\mathbf{b}}$} \\
\hline Model & $\mathrm{R}$ & R Square & Adjusted R Square & Std. Error of the Estimate \\
\hline 1 & $.880^{\text {a }}$ & .774 & .772 & 3.085 \\
\hline \multicolumn{4}{l}{ a. Predictors: (Constant), kinerja guru, manajemen kepala sekolah } \\
\hline \multicolumn{4}{l}{ b. Dependent Variable: minat belajar }
\end{tabular}

Berdasarkan hasil SPSS di atas besarnya presentase pengaruh variabel manajemen kepala sekolah dan kinerja guru terhadap variabel minat belajar. besarnya $\mathrm{R}$ Square yaitu 0,774 yang berarti bahwa besarnya pengaruh manajemen kepala sekolah terhadap minat belajar sebesar $74 \%$ dan $22,6 \%(100 \%$ 77,4\%) dipengaruhi variabel lain.

Tabel 12. Hasil Analisis Rergresi Manajemen Kepala Sekolah dan Kinerja Kerja terhadap Minat Belajar

\begin{tabular}{|c|c|c|c|c|c|c|}
\hline \multicolumn{7}{|c|}{ ANOVA $^{b}$} \\
\hline Model & & $\begin{array}{l}\text { Sum of } \\
\text { Squares }\end{array}$ & Df & Mean Square & $\mathrm{F}$ & Sig. \\
\hline \multirow[t]{3}{*}{1} & Regression & 8222.943 & 2 & 4111.471 & 432.068 & $.000^{\mathrm{a}}$ \\
\hline & Residual & 2397.983 & 252 & 9.516 & & \\
\hline & Total & 10620.925 & 254 & & & \\
\hline
\end{tabular}

a. Predictors: (Constant), kinerja guru, manajemen kepala sekolah

b. Dependent Variable: minat belajar

Berdasarkan hasil SPSS niali signifikan 0,000. Signi. tabel ANOVA 0,000 kurang dari 0,05. Hal tersebut menunjukkan bahwa Ho ditolak dan Ha diterima yang berarti bahwa terdapat pengaruh antara manajemen kepala sekolah dan kinerja guru terhadap minat belajar.

Tabel 13. Perhitungan Nilai B Persamaan Regresi Manajemen Kepala Sekolah dan Kinerja Guru terhadap

Minat Belajar

\section{Coefficients $^{\mathrm{a}}$}

\begin{tabular}{|c|c|c|c|c|c|c|c|c|}
\hline \multirow{2}{*}{\multicolumn{2}{|c|}{ Model }} & \multicolumn{2}{|c|}{$\begin{array}{l}\text { Unstandardized } \\
\text { Coefficients }\end{array}$} & \multirow{2}{*}{$\begin{array}{c}\begin{array}{c}\text { Standardized } \\
\text { Coefficients }\end{array} \\
\text { Beta }\end{array}$} & \multirow[b]{2}{*}{$\mathrm{t}$} & \multirow[b]{2}{*}{ Sig. } & \multicolumn{2}{|c|}{$\begin{array}{l}95 \% \text { Confidence } \\
\text { Interval for B }\end{array}$} \\
\hline & & B & Std. Error & & & & $\begin{array}{l}\text { Lower } \\
\text { Bound }\end{array}$ & $\begin{array}{l}\text { Upper } \\
\text { Bound }\end{array}$ \\
\hline \multirow[t]{3}{*}{1} & (Constant) & 6.512 & 2.422 & & 2.689 & .008 & 1.743 & 11.281 \\
\hline & $\begin{array}{l}\text { manajemen kepala } \\
\text { sekolah }\end{array}$ & . 175 & .059 & .177 & 2.989 & .003 & .060 & .291 \\
\hline & kinerja guru & .751 & .061 & .723 & 12.205 & .000 & .629 & .872 \\
\hline
\end{tabular}

a. Dependent Variable: minat belajar 
1994 Pengaruh Manajemen Kepala Sekolah dan Kinerja Guru terhadap Minat Belajar Siswa di Sekolah DasarAnita Turisi, Suhartono, Rais Hidayat

DOI: https://doi.org/10.31004/edukatif.v3i4.1044

Berdasarkan tabel coefficients di atas kolom B pada constant adalah 6,512 sedangkan manajemen kepala sekolah adalah 0,175 dan kinerja guru 0,751 . Sehingga persamaan regresinya dapat ditulis sebagai berikut:

$$
\begin{aligned}
& Y=a+b_{1} X_{1}+b_{2} X_{2} \\
& Y=6,512+0,175 X-1+0,751 X-2
\end{aligned}
$$

Nilai signifikansi dapat dijadikan pedoman untuk mengetahui bahwa terdapat pengaruh atau tidak antara manajemen kepala sekolah dan kinerja guru terhadap minat belajar. Dalam memeberikan interprestasi dengan menggunakan nilai signifikaansi dengan ketentuan:

a. Apabila (sig. $\leq 0,05)$ berarti pengaruh variabel bebas terhadap variabel terikat signifikan

b. Apabila (sig. > 0,05) berarti pengaruh variabel bebas terhadap variabel terikat tidak signifikan.

Berdasarkan output SPSS 25.0 menunjukkan variabel manajemen kepala sekolah nilai signifikan 0,003 kurang dari 0,05 . Hal tersebut berarti terdapat pengaruh yang signifikan antara manajemen kepala sekolah terhadap minat belajar.

\section{Pengaruh Manajemen Kepala Sekolah terhadap Minat Belajar}

Hasil uji hipotesis ke-1, menyatakan bahwa terdapat pengaruh positif dan signifikan manajemen kepala sekolah terhadap minat belajar. Hal tersebut dibuktikan berdasarkan output juga menerangkan presentase pengaruh dengan R Square. Nilai R Square yaitu 0.641 yang artinya besarnya pengaruh manajemen kepala sekolah terhadap minat belajar adalah 64,1\%. Sedangkan 35,9\% (100\% - 64,1\%) dipengaruhi variabel lain. Berdasarkan nilai signifikan 0,000. Sig. pada tabel ANOVA 0,000 kurang dari 0,05. Sehingga Ho di tolak dan Ha diterima yang artinya terdapat pengaruh antara manajemen kepala sekolah terhadap minat belajar.

Berdasarkan hasil penelitian di atas menyatakan bahwa manajemen kepala sekolah berpengaruh terhadap minat belajar siswa. Semakin tinggi dan bagus manajemen kepala sekolah akan semakin tinggi serta baik minat belajar siswa. Begitu juga sebaliknya makin rendah manajemen kepala sekolah makin rendah juga minat belajar siswa. Hasil penelitian ini mendukung penelitian terdahulu yang dilakukan oleh Marhama (2014). Penelitian lain yang mendukung penelitian ini adalah penelitian yang dilakukan oleh Anna Ma'ratuz Zahro, Ahmad Yusuf Sobri, Ahmad Nurabadi (2018), dimana dalam penelitian ini menghasilkan mengenai (1) tugas kepala sekolah sebagai pimpinan perubahan adalah bertugas sebagai visioner, melatih, memicu, dan rekan kerja, (2) metodologi yang digunakan oleh kepala sekolah adalah untuk meningkatkan manajerial siswa dan manajerial gurudan karyawan, menumbuhkan budaya sekolah, mengatur pembelajaran, dan mengatur hasil dengan maksimal. Bahwa peran kepala sekolah sebagai pemimpin maka kepala sekolah harus mempunyai tanggung jawab terhadap guru dan siswa, untuk itu secara tidak langsung kepala sekolah melalui guru dalam kinerjanya untuk selalu memberikan perhatian kepada siswa supaya mempunyai motivasi, minat dan prestasi belajar. Teori yang mendukung pengaruh manajemen kepala sekolah terhadap minat belajar adalah teori James memaparkan bahwa kepala sekolah harus melakukan lima aktivitas utama, antara lain: 1) merumuskan visi untuk kemajuan akademik siswa; 2) menciptakan suasana sekolah yang sangat kayak untuk pendidikan danpembelajaran; 3) menanamkan sikap kepemimpinan terhadap seluruh staf akademik dan nonakademik; 4) meningkatkan pembelajaran, dan 5) mengelola seluruh staf akademik dan non-akademik untuk mengelola proseslayanan akademik dan non-akademik dalam rangka mempercepat kemajuan (Fitrah, 2017).

\section{Pengaruh Kinerja Guru terhadap Minat Belajar}

Hasil pengujian hipotesis kedua menunjukkan bahwa kinerja guru berpengaruh positif terhadap minat belajar. Hal tersebut dibuktikan dengan nilai $\mathrm{R}$ Square yaitu 0,766 yang berari besarannya pengaruh kinerja guru terhadap minat belajar yaitu 76,6\%. Dan 23,4\% (100\% - 76,6\%) dipengaruhi oleh variabel lain. Selain itu nilai signifikan 0,000. Signifikan pada tabel ANOVA 0,000 kurang dari 0,05. Sehingga Ho ditolak dan Ha diterima yang artinya terdapat pengaruh antara variabel kinerja guru terhadap minat belajar. Hasil penelitian 
1995 Pengaruh Manajemen Kepala Sekolah dan Kinerja Guru terhadap Minat Belajar Siswa di Sekolah DasarAnita Turisi, Suhartono, Rais Hidayat

DOI: https://doi.org/10.31004/edukatif.v3i4.1044

mendukung penelitian yang dilakukan oleh Eko Putro, Widoyoko dan Anita Rinawati (2013), menunjukkan bahwa terdapat pengaruh kinerja guru terhadap minat belajar siswa. Artinya, semakin tinggi guru dalam menguasai materi pembelajaran, mampu mengelola pembelajaran dengan baik, mampu melaksanakan pembelajaran lebih menarik, guru yang menguasai beragam strategi pembelajaran dengan baik, akan semakin meningkatkan minat belajar siswa. Sebaliknya, bagi guru yang kurang menguasai materi pembelajaran, guru yang minim penguasaan strategi pembelajaran, kegiatan pembelajaran yang dilaksanakan menjadi kurang menarik hal ini akan menurunkan minat belajar siswa. Penelitian lain yang mendukung adalah penelitian Andi Rahman Amanah, Hasan Nongkeng, dan Budiman (2018), dimana hasil penelitian menyatakan kinerja guru berpengaruh terhadap minat belajar, yang artinya semakin tinggi kinerja guru maka semakin tinggi minat belajar siswa begitu juga makin rendah kinerja guru maka makin rendah minat belajar siswa, sehingga disini guru dituntut untuk mempunyai kinerja yang tinggi karena akan berpengaruh terhadap minat belajar siswa.

Penelitian ini juga didukung oleh teori Nurkacana, bahwa seorang guru sebaiknya mau dan mampu memelihara minat anak didiknya, dengan berbagai cara yang ditawarkan, yaitu: 1) meningkatkan minat anak, setiap guru mempunyai kewajiban untuk menigkatkan minat siswanya. Karena minat komponen yang sangat penting dalam pendidikan terutama dalam proses pembelajaran yang terjadi di kelas; 2) mengembangkan minat, jika siswa memperlihatkan kurangnya minat, dan kewajiban pendidik dalah mengembangkan minat siswa; 3) mengantisipasi adanya penyimpangan minat kea rah yang negatif, sekolah adalah tempat pendidikan yang bertugas untuk mencetak siswa agar dapat menumbuhkan bakat-bakat yang baik yang dapat digunakan sebagai bekal dalam lingkungan masyarakat; 4) menjadikan rencana dalan memberikan pengarahan kepada siswa mengenai pendidikan lanjut yang sesuai dengan bakat dan minatnya, minat dapat dijadikan sebagai bahan pertimbangan dalam mengerti kesukaan siswa (Susanto, 2019).

\section{Pengaruh Manajemen Kepala Sekolah dan Kinerja Guru terhadap Minat Belajar}

Hasil analisis regresi berganda menunjukkan bahwa besarnya nilai $\mathrm{R}$ Square yaitu 0,774 yang artinya bahwa besarnya pengaruh manajemen kepala sekolah, kinerja guru terhadap minat belajar yaitu 77,4\%. Dan $22,6 \%(100 \%-77,4 \%)$ dipengaruhi variabel lain. Nilai signifikan 0,000. Signifikan pada tabel ANOVA 0,000 kurang dari 0,05. Sehingga Ho ditolak dan Ha diterima yang artinya terdapat pengaruh antara manajemen kepala sekolah dan kinerja guru terhadap minat belajar. Hasil penelitian ini mendukung penelitian terdahulu oleh Setiyati (2014), diamana hasil penelitian menunjukkan ada pengaruh positif yang signifikan antara kepemimpinan kepala sekolah, motivasi kerja dan budaya sekolah secara bersama-sama terhadap kinerja guru. Hal ini dapat diartikan bahwa kepimpinan kepala sekolah yang meningkat, motivasi kerja yang baik serta budaya sekolah yang kondusif memberikan dukungan terhadap kinerja guru menjadi lebih meningkat. Pada saat kinerja guru meningkat disini akan berpengaruh terhadap minat belajar secara tidak langsung.

Penelitian terdahulu yang mendukung penelitian ini adalah penelitian yang dilakukan oleh H. Hardono., Haryono, H., \& Yusuf, A. (2017), hasil penelitian menunjukkan ada pengaruh yang positif dan signifikan kepemimpinan kepala sekolah, supervisi akademik dan motivasi kerja terhadap kinerja guru. Artinya, kepemimpinan kepala sekolah, supervisi akademik dan motivasi kerja yang baik akan meningkatkan kinerja guru. Kepala sekolah mempunyai peranan dalam mengatur dan mengelola segala sumber daya ada di sekolah, dalam hal ini kinerja guru diawasi oleh kepala sekolah. Kepala sekolah mengawasi hasil kerja yang telah dicapai guru dalam pembelajaran berdasarkan atas ketentuan dari pihak yang berwenang di Indonesia. Kinerja guru mencakup perencanaan proses pembelajaran, pelaksanaan proses pembelajaran, penilaian hasil pembelajaran, dan pengawasan proses pembelajaran. Ketika kinerja guru bagus sehingga akan berpengaruh terhadap minat belajar siswa. 
1996 Pengaruh Manajemen Kepala Sekolah dan Kinerja Guru terhadap Minat Belajar Siswa di Sekolah DasarAnita Turisi, Suhartono, Rais Hidayat

DOI: https://doi.org/10.31004/edukatif.v3i4.1044

\section{KESIMPULAN}

Berdasarkan hasil penelitian dan pembahasan, simpulan penelitian ini meliputi: (1) terdapat pengaruh manajemen kepala sekolah terhadap minat belajar, telah dibuktikan dengan hasil uji hipotesis yang pertama dalam penelitian ini menunjukkan signifikansi tabel ANOVA 0,000 kurang dari 0,05 yang berarti Ho ditolak dan Ha diterima; (2) terdapat pengaruh antara variabel kinerja guru terhadap minat belajar, terbukti dengan hasil uji hipotesis kedua yang menunjukkan nilai signifikansni tabel ANOVA 0,000 kurang dari 0,05 yang berarti Ho ditolak dan Ha diterima; dan (3) terdapat pengaruh antara variabel manajemen kepala sekolah dan kinerja guru terhadap minat belajar. Terbukti dengan hasil analisis regresi berganda yang menunjukkan nilai signifikan 0,000. Sig. pada tabel ANOVA 0,000 kurang dari 0,05 yang artinya Ho ditolak dan Ha diterima.

\section{UCAPAN TERIMA KASIH}

Terima kasih saya ucapakan kepada keluarga, dosen pembimbing yang telah membimbing dan memberikan ilmu yang sangat bermanfaat demi penyelesaian TAPM ini, rekan-rekan mahasiswa Prodi Magister Pendidikan Dasar Universitas Terbuka, seluruh dosen dan staff UPBJJ UT Purwokerto yang telah membantu peneliti dalam menyelesaikan penelitian ini.

\section{DAFTAR PUSTAKA}

Ahmad Susanto. (2016). Teori Belajar Dan Pembelajaran Di Sekolah Dasar. Prenadamedia Group.

Fitrah, M. (2017). Peran Kepala Sekolah Dalam Meningkatkan Mutu Pendidikan. Jurnal Penjaminan Mutu, $3(1), 31-42$.

Hardono, H., Haryono, H., \& Yusuf, A. (2017). Kepemimpinan Kepala Sekolah, Supervisi Akademik, Dan Motivasi Kerja Dalam Meningkatkan Kinerja Guru. Educational Management, 6(1), 26-33.

Hasibuan, M. S. P. (2007). Manajemen Sumber Daya Manusia Perusahaan. PT. Bumi Aksa.

Herujito, Y. M. (2004). Dasar-Dasar Manajemen. Grasindo.

Kurniatun, T. C., \& Suryana, A. (2016). Kepemimpinan Dan Manajemen Pendidikan Dasar. Universitas Terbuka.

Marhama. (2014). Pengaruh Kinerja Manajemen Kepala Madrasah Dan Kinerja Mengajar Guru Terhadap Motivasi Belajar Siswa Madrasah Aliyah Negeri (MAN) Majene. UIN Alaudin Makassar.

Nugraha, M. S. (2014). Pelaksanaan Supervisi Akademik Oleh Kepala Madrasah Aliyah Swasta Di Kabupaten Sukabumi Jawa Barat. Nadwa: Jurnal Pendidikan Islam, 9(1), 39-68.

Nurhasanah, S., \& Sobandi, A. (2016). Minat Belajar Sebagai Determinan Hasil Belajar Siswa. Jurnal Pendidikan Manajemen Perkantoran (Jpmanper), 1(1), 128-135.

Putro, S. E., Rinawati, A., \& Muh, U. (2013). Pengaruh Kinerja Guru Terhadap Motivasi Belajar Siswa. Jurnal Cakrawala Pendidikan, 5(2), 278-289.

Raharjo, S. B., \& Yuliana, L. (2016). Manajemen Sekolah Untuk Mencapai Sekolah Unggul Yang Menyenangkan: Studi Kasus Di SMAN 1 Sleman Yogyakarta. Jurnal Pendidikan Dan Kebudayaan, 119716.

Setiyati, S. (2014). Pengaruh Kepemimpinan Kepala Sekolah, Motivasi Kerja, Dan Budaya Sekolah Terhadap Kinerja Guru. Jurnal Pendidikan Teknologi Dan Kejuruan, 22(2), 200-206.

Susanto, A. (2019). Konsep, Strategi, Dan Implementasi Manajemen Peningkatan Kinerja Guru. Prenadamedia Group.

Zahro, A. M., Sobri, A. Y., \& Nurabadi, A. (2018). Kepemimpinan Perubahan Kepala Sekolah Dalam Peningkatan Mutu Pendidikan. JAMP: Jurnal Administrasi Dan Manajemen Pendidikan, 1(3), 358-363.

Zakso, A., Agung, I., \& Capnary, M. C. (2018). The Influence Of Principal Leadership, Teacher Learning 
1997 Pengaruh Manajemen Kepala Sekolah dan Kinerja Guru terhadap Minat Belajar Siswa di Sekolah Dasar Anita Turisi, Suhartono, Rais Hidayat

DOI: https://doi.org/10.31004/edukatif.v3i4.1044

Characteristics, And Utilization Facilities On Student Thinking Skill. International Journal Of Educational Policy Research And Review, 5(9), 166-173. 